\title{
PŘEHLED AKTUÁLNÍ JUDIKATURY I/2021
}

VOJTĚCH BARTOŠ, FRANTIŠEK KASL, JAKUB KLODWIG, IVANA KUDLÁČKOVÁ, PAVEL LOUTOCKÝ, JAKUB MÍŠEK, JAKUB VOSTOUPAL

\section{PRÁVO DUŠEVNÍHO VLASTNICTVÍ}

\section{NÁROK NA JEDINOU SPRAVEDLIVOU ODMĚNU ZA SDĚLOVÁNÍ ZVUKOVÝCH ZÁZNAMŮ, JEŽ JSOU SOUČÁSTÍ AUDIOVIZUÁLNÍCH DĚL}

\author{
Soud: $\quad$ Soudní dvůr Evropské unie \\ Věc: $\quad$ C-147/19 (Atresmedia) \\ Datum: $\quad$ 18. 11.2020 \\ Dostupnost: curia.europa.eu
}

Předmětem řízení o předběžné otázce byl spor mezi španělskou televizní společností Atresmedia a španělskými správci duševního vlastnictví výrobců zvukových záznamů a práva výkonných umělců ohledně platby jediné spravedlivé odměny za sdělování audiovizuálních děl, jejichž součástí jsou zvukové záznamy, na televizních kanálech společnosti Atresmedia.

Televizní společnost zakomponovala do vysílaných audiovizuálních děl zvukové záznamy, a tyto pak prostřednictvím svých kanálů sdělovala veřejnosti. Strany se přely o otázku, zda takto sdělovaný obsah lze považovat za zvukový záznam, a tedy zda za jeho užití náleží výkonným umělcům a výrobcům př́slušného zvukového záznamu jediná spravedlivá odměna.

Jádrem sporu byl výklad čl. 8 odst. 2 směrnice 92/100/ES, resp. směrnice 2006/115/ES, na základě kterého mají členské státy zajistit zaplacení je- 
diné spravedlivé odměny, pokud je užito zvukového záznamu vydaného $\mathrm{k}$ obchodním účelům nebo rozmnoženiny takového záznamu k bezdrátovému vysílání nebo jakémukoliv jinému sdělování veřejnosti. Článek 3 Úmluvy o ochraně výkonných umělců, výrobců zvukových záznamů a rozhlasových organizací (Římská úmluva) stanoví, že zvukovým záznamem je každý výlučně sluchem vnímatelný záznam zvuků uměleckého výkonu nebo jiných zvuků. Článek 2 písm. b) Smlouvy WIPO o právu autorském a Smlouvy WIPO o výkonech výkonných umělců a o zvukových záznamech (WPTT) definuje zvukový záznam jako záznam zvuků výkonu nebo jiných zvuků, anebo vyjádření zvuků, jiných než ve formě záznamu obsaženého ve filmovém nebo jiném audiovizuálním díle.

V rámci své analýzy Soudní dvưr konstatoval, že ač EU není signatářem Římské úmluvy, je při absenci definice pojmu „zvukový záznam“ v unijním právu Soudní nutné přistoupit $\mathrm{k}$ jeho výkladu dle mezinárodního práva. To proto, že příslušné směrnice používající daný pojem mají „provést“ příslušné mezinárodní právní instrumenty. ${ }^{1}$ Tento účel posuzovaných ustanovení směrnic prritom Soudní dvưr vyčetl zejména $\mathrm{z}$ důvodové zprávy předcházející směrnici 92/100/ES. ${ }^{2}$ Soudní dvưr také výslovně konstatoval, že Římská úmluva má v rámci unijního práva nepřímý účinek. ${ }^{3}$ Soudní dvưr rovněž připomněl, že také dle WPTT nemůže být zvukový záznam začleněný do audiovizuálního záznamu považován za samostatný zvukový záznam pro účely odměny, pakliže výsledný audiovizuální záznam má status samostatného díla. ${ }^{4}$ Na tomto závěru Soudního dvora nic nemění ani společné prohlášení přijaté diplomatickou konferencí k čl. 2 písm. b) WPTT, na základě kterého práva $\mathrm{k}$ zvukovému záznamu jeho začleněním do filmového nebo jiného audiovizuálního díla zůstávají nedotčena. ${ }^{5}$ Soudní dvůr toto prohlášení chápe tak, že nedotčena zůstávají práva ke zvukovému záznamu

\footnotetext{
Bod 34 anotovaného rozhodnutí.

Bod 35 anotovaného rozhodnutí.

Bod 36 anotovaného rozhodnutí.

Bod 40 anotovaného rozhodnutí.

Bod 42 anotovaného rozhodnutí.
} 
samotnému, nikoliv však do té míry nakolik je součástí audiovizuálního díla. ${ }^{6}$

Z anotovaného rozhodnutí Soudního dvora tedy vyplývá zejména fakt, že audiovizuální nahrávku obsahující záznam audiovizuálního díla nelze kvalifikovat jako „zvukový záznam“ nebo „rozmnoženinu takového záznamu“ ve smyslu čl. 8 odst. 2 směrnice $92 / 100$ nebo čl. 8 odst. 2 směrnice 2006/115, a tedy sdělování takové nahrávky veřejnosti nezakládá nárok na odměnu stanovenou v těchto ustanoveních. ${ }^{7}$

Autor: VB

\section{NEPŘEZKOUMATELNÉ PROHLÁŠENÍ NEPLATNOSTI OCHRANNÉ ZNÁMKY CZECH POINT}

Soud: $\quad$ Nejvyšší správní soud

Věc: $\quad 5$ As $112 / 2018-53$

Datum: $\quad$ 22. 1.2021

Dostupnost: nssoud.cz

Předmětem sporu bylo rozhodnutí Úřadu průmyslového vlastnictví (dále jen „ÚPV“) ze dne 7. 1. 2012, kterým byla na základě návrhu Ministerstva vnitra (dále jen „MV“) prohlášena za neplatnou ochranná známka „CZECH POINT“ jakožto spekulativní s ohledem na veřejnou známost projektu elektronizace státní správy a zřizování kontaktních míst s označením CZECHPOINT. ${ }^{8}$ Ochranná známka byla zapsaná do rejstř́ku ochranných známek ve prospěch společnosti CZECH POINT 101 s.r.o. (dále jen „CP101“) dne 16. 4. 2007 s právem přednosti ode dne 5. 4. $2006 .^{9}$

Rozklad proti rozhodnutí byl v roce 2013 předsedou ÚPV zamítnut, následný rozsudek městského soudu z roku 2016 na základě správní žaloby CP101 byl Nejvyšším správním soudem (dále jen „NSS“) roku 2017 zrušen

\footnotetext{
Bod 44 anotovaného rozhodnutí.

Bod 52 - 53 anotovaného rozhodnutí.

Body 2-3 anotovaného rozhodnutí.

9 Bod 1 anotovaného rozhodnutí.
} 
pro nepřezkoumatelnost. ${ }^{10}$ Městský soud v Praze následně v roce 2018 ve věci znovu rozhodl ve prospěch $\mathrm{CP} 101$ a vyhodnotil zamítavé rozhodnutí předsedy ÚPV o rozkladu jako „nepřezkoumatelné, nebot’ většina jeho závěrů jsou pouhé spekulace “. ${ }^{11}$ Proti tomuto rozsudku podali ÚPV i MV kasační stížnosti, kterými se NSS zabýval v anotovaném rozhodnutí.

Stěžovatelé se kasačními stížnostmi domáhali zrušení rozsudku městského soudu pro jeho nesprávnost a neodůvodněnost a vrácení věci $\mathrm{k}$ dalšímu ř́zení. ${ }^{12}$ CP101 označila rozsudek za souladný se závazným názorem předcházejícího rozhodnutí NSS a navrhla zamítnutí kasačních stížností pro nepř́ípustnost. ${ }^{13}$ NSS nejprve dovodil, že na rozhodnutí NSS o nepřezkoumatelnosti nelze vztáhnout judikaturu NSS ${ }^{14}$ omezující přípustnost opakované kasační stížnosti, následně pak obě kasační stížnosti shledal za nedůvodné a zamítl je. ${ }^{15}$

NSS předně zdůraznil, že pro posouzení dobré či zlé víry přihlašovatele ochranné známky nelze přikládat vliv okolnostem po okamžiku podání přihlášky. ${ }^{16}$ To přitom ÚPV při svém hodnocení do značné míry činí. ${ }^{17}$ Dále soud zdůraznil potřebu vycházet $\mathrm{z}$ presumpce dobré víry přihlašovatele, jednat při posuzování nestranně a přihlížet ke všem relevantním okolnostem př́padu. ${ }^{18} \mathrm{~V}$ jednání před městským soudem přitom byla na základě výpovědi svědků zpochybněna klíčová skutečnost, a to známost spojení projektu elektronizace státní správy s pojmem CZECHPOINT širší veřejnosti v okamžiku podání přihlášky. ${ }^{19}$ NSS nadto přímo konstatoval, že skutkový stav zjištěný ÚPV ,je v rozporu s obsahem spisu a provedenými dů-

\footnotetext{
10 Bod 4 anotovaného rozhodnutí.

11 Bod 5 anotovaného rozhodnutí.

12 Body 19 a 27 anotovaného rozhodnutí.

13 Body 36 a 37 anotovaného rozhodnutí.

14 Např. rozsudek NSS ze dne 10.6.2008, č.j. 2 Afs 26/2008-119.

15 Body 38 a 39 anotovaného rozhodnutí.

16 Bod 41 anotovaného rozhodnutí, s odkazem na rozsudky NSS ze dne 23.4.2010, č.j. 5 As 17/2009-152 a ze dne 22.5.2014, č.j. 7 As 151/2012-64.

17 Srov. body 53-54 a 69-71 anotovaného rozhodnutí.

18 Bod 44 anotovaného rozhodnutí.

19 Bod 47 anotovaného rozhodnutí.
} 
kazy“, hodnocení důkazů je do značné míry jednostrannée ${ }^{20}$ a skutková zjištění z provedených důkazů „jsou bud' „překroucená“, anebo $v$ nich dokonce nemají žádnou oporu a následné skutkové závěry jsou tak pouhými nepodloženými spekulacemi. “" ${ }^{21}$ Nedostatek odůvodnění správního aktu přitom nemůže být dodatečně zhojen ani v následném soudním řízení, ani analýzou v kasační stížnosti. ${ }^{22}$

$\mathrm{V}$ dalším řízení je na místě důsledně vyhodnotit, co bylo v rozhodném okamžiku skutečně známo veřejnosti a zda právo svědčilo MV, přičemž „na nedobrou víru nelze automaticky usuzovat jen ze skutečností, které nastaly po podání přihlášky" a CP101 nelze klást $\mathrm{k}$ tíži, že vưči MV uplatňovala svá tvrzená práva. ${ }^{23}$

Autor: FK

\section{JE ZPŘíSTUPŇOVÁNí CHRÁNĚNÝCH DĚL PROSTŘEDNICTVÍM FRAMINGU SDĚLOVÁNÍM VEŘEJNOSTI?}

Soud: $\quad$ Soudní dvůr Evropské unie

Věc: $\quad$ C-392/19 (VG Bild-Kunst)

Datum: $\quad$ 9. 3. 2021

Dostupnost: curia.europa.eu

Stiffung Preußischer Kulturbesitz, německá nadace kulturního dědictví je provozovatelem digitální knihovny spojující německé kulturní a vědecké instituce. Internetové stránky této knihovny obsahují odkazy ve formě náhledů (Thumbnails) na digitalizovaný obsah zúčastněných institucí, přičemž při kliknutí na náhled je uživatel ihned přesměrován na stránky relevantní organizace. ${ }^{24}$ Organizace VG Bild-Kunst, kolektivní správce autorských práv v oblasti vizuálních umění, obecně podmiňuje uzavírání licenčních smluv implementací technologických prostředků proti framingu náhledů chráně-

\footnotetext{
${ }^{20}$ Blíže viz body 76-77 anotovaného rozhodnutí.

${ }^{21}$ Bod 51, dále pak konkrétněji body 55-68 anotovaného rozhodnutí.

${ }^{22}$ Body 72 a 75 anotovaného rozhodnutí.

${ }^{23}$ Bod 80 anotovaného rozhodnutí.

${ }^{24}$ Viz bod 10 anotovaného rozhodnutí.
} 
ných děl. ${ }^{25}$ Toto bylo ze strany nadace SPK považováno za nepřiměřenou podmínku a na VG Bild-Kunst podala žalobu. ${ }^{26}$

Zemský soud v Berlíně tuto žalobu zamítl, což záhy zrušil vrchní zemský soud. Kolektivní správce práv se nyní domáhá prostřednictvím opravného prostředku zamítnutí žaloby u Spolkového soudního dvora. Ten zdůraznil, že organizace kolektivní správy má dle německého práva ${ }^{27}$ obecně povinnost poskytnout licenci každé osobě, která o to požádá, za přiměřených podmínek. ${ }^{28}$ Výsledek řízení závisí na tom, zda framing představuje nové sdělování díla veřejnosti, nebơ v takovém případě by VG Bild-Kunst mohla oprávněně podmiňovat udělení licence implementací technologických protiopatření. ${ }^{29}$

S ohledem na judikaturu Soudního dvora Evropské unie týkající se framingu $^{30}$ a svobody projevu v digitálním kontextu, ${ }^{31}$ položil Spolkový soudní dvůr předběžnou otázku, zda zveřejnění chráněných děl prostřednictvím framingu lze klasifikovat jako nové sdělování díla veřejnosti. ${ }^{32}$

Právo kontroly autorů (at̉ už souhlas, omezení či zákaz) nad jakýmkoliv sdělením jejich děl veřejnosti skrze jakékoliv prostředky zakotvuje prostřednictvím povinnosti členských států takové právo autorům přiznat první odstavec článku 3 směrnice 2001/29/ES.

Soudní dvůr připomněl, že sdělování děl veřejnosti je $\mathrm{z}$ důvodu vyšší ochrany autorů nutné vykládat extenzivně, ${ }^{33} \mathrm{i}$ zveřejňování prostřednictvím náhledů tak představuje sdělení veřejnosti, které podléhá nutnému svolení

${ }^{25}$ Viz bod 11 anotovaného rozhodnutí.

${ }^{26}$ Viz bod 12 anotovaného rozhodnutí.

${ }^{27}$ Které provádí unijní směrnici 2014/26, o kolektivní správě autorského práva a práv s ním souvisejících a udělování licencí pro více území $\mathrm{k}$ právưm $\mathrm{k}$ užití hudebních děl online na vnitřním trhu.

${ }^{28}$ Od tohoto se může odchýlit, pokud se tím nezneužije monopol a existuje legitimní cíl takového odchýlení (napřr. zájmy dotyčných osob). Viz body 12-15 anotovaného rozhodnutí.

${ }^{29}$ Viz body 14-17 anotovaného rozhodnutí.

${ }^{30}$ Usnesení ze dne 21. října 2014, BestWater International, C-348/13, nezveřejněné, EU:C:2014:2315.

${ }^{31}$ Viz bod 45 rozsudku ze dne 8. září 2016, GS Media, C-160/15, EU:C:2016:644. Jedná se o judikaturu, ze které vyplývá, že hypertextové odkazy přispívají k řádnému fungování internetu, výměně názorů a informací.

${ }^{32}$ Viz bod 18 anotovaného rozhodnutí. 
nositelů práv. ${ }^{34}$ Metoda framingu představuje $\mathrm{v}$ souladu $\mathrm{s}$ judikaturou Soudního dvora sama o sobě sdělení veřejnosti, ${ }^{35}$ otázkou bylo, zda se $\mathrm{v}$ tomto případě jedná o další sdělení, tedy prostřednictvím nové technologie či vůči nové veřejnosti, nebơ takové sdělení by vyžadovalo nový souhlas. ${ }^{36} \mathrm{~V}$ porovnání s jinými př́pady, ${ }^{37} \mathrm{kdy}$ autor nevyužil opatření $\mathrm{k}$ omezení prrístupu a zveřejnění díla tak proběhlo v podstatě vưči celé „internetové“ veřejnosti, zde vyžadoval nositel práv implementaci omezujících opatření ${ }^{38}$ a tím souhlas fakticky cílil na specifickou veřejnost, uživatele na specifických stránkách. Nikoliv na širokou internetovou veřejnost, vůči které dochází ke zveřejnění prostřednictvím framingu. ${ }^{39}$ Pokud by tedy odkaz (např. právě framing) umožňoval obejít opatření omezující př́stup ke chráněným dílům, pak by přístup, který by vyžadoval dosah prvotního souhlasu nositelů práv i na tento případ, odepíral nositelům práv faktickou kontrolu nad chráněným dílem a zaváděl by vyčerpání práva na sdělování. ${ }^{40}$

Soudní dvůr tedy uzavřel, že vložení chráněných děl, která jsou zpřístupněna specifické veřejnosti na internetových stránkách se souhlasem autora, prostřednictvím techniky framingu na jiné internetové stránky a obejití prostředků ochrany proti framingu požadovaných autorem, představuje sdělování díla nové veřejnosti.

Autor: JV

\footnotetext{
33 Viz rozsudek ze dne 19. prosince 2019, Nederlands Uitgeversverbond a Groep Algemene Uitgevers, C-263/18, EU:C:2019:1111, bod 49 a citovaná judikatura; a bod 26 anotovaného rozhodnutí.

34 Viz body 20-23 anotovaného rozhodnutí.

35 Viz body 33-35 anotovaného rozhodnutí a body 20, 22 a 23 rozsudku ze dne 13. února 2014, Svensson a další, C-466/12, EU:C:2014:76.

36 Viz body 35-37 anotovaného rozhodnutí.

37 Viz body 37-38 anotovaného rozhodnutí.

38 Viz body 39-40 anotovaného rozhodnutí.

39 Viz body 42-50 anotovaného rozhodnutí.

40 Viz body 51-55 anotovaného rozhodnutí.
} 


\section{SOUKROMÍ A OSOBNÍ ÚDAJE}

\section{DATA RETENTION OBECNĚJI}

Soud: $\quad$ Soudní dvůr Evropské unie

Věc: $\quad$ C-511/18 (La Quadrature du Net a další)

Datum: $\quad$ 6. 10.2020

Dostupnost: curia.europa.eu

Anotované rozhodnutí věcně navazuje na předchozí rozhodovací praxi Soudního dvora, zejména pak rozhodnutí Tele2 Sverige (spojené věci C-203/15 a C-698/15). Dále precizuje podmínky, za kterých mohou členské státy zavést takovou právní úpravu, která zakládá povinnost provozovatelům elektronických komunikací uchovávat provozní a lokalizační údaje, a která dále umožňuje příslušným orgánům veřejné moci tyto údaje využívat. Soudní dvůr nyní rozhodoval ve třech spojených věcech, které se všechny v základu týkaly otázky, jak daleko sahá výjimka čl. 15 odst. 1 směrnice 2002/58/ES, která umožňuje uchovávání a další zpracování provozních a lokalizačních údajů za účely nezbytnými pro „zajištění národní bezpečnosti, obrany, veřejné bezpečnosti a pro prevenci, vyšetřování, odhalování a stíhání trestných činů. “41

Soudní dvůr předně připomněl, že pro výklad ustanovení unijního práva je třeba krom jeho textu zohlednit i jeho kontext a účel právní úpravy, ${ }^{42}$ přičemž cílem směrnice 2002/58 je zajištění dodržování práv zakotvených v čl. 7 a 8 Listiny základních práv EU. Soudní dvůr dále připomíná, že z provozních a lokalizačních údajů je možné odhalit celou řadu citlivých informací o soukromém životě člověka, ${ }^{43}$ a že při vyhodnocování možnosti aplikace výjimky je nutné vzít v potaz i další základní práva garantovaná Listinou. ${ }^{44}$ Soudní dvůr tak opětovně uvádí, že tuto výjimku není možné aplikovat pro vytvoření obecné, plošné a preventivní povinnosti uchovávat

\footnotetext{
41 Čl. 15 odst. 1 směrnice 2002/58/ES.

42 Bod 105 anotovaného rozhodnutí.

43 Bod 117 anotovaného rozhodnutí.

44 Body 122 a následující anotovaného rozhodnutí.
} 
provozní a lokalizační údaje. Naopak, za účelem splnění požadavku proporcionality „musí právní úprava stanovit jasná a presná pravidla pro rozsah a použití předmětného opatření a uložit minimální požadavky, tak aby osoby, o jejichž osobní údaje jde, měly dostatečné záruky umožňující účinně chránit tyto údaje před rizikem zneužití. Tato právní úprava musí být právně závazná ve vnitrostátním právu a musí zejména vymezit okolnosti a podmínky, za nichž může být prìjato opatření týkající se zpracovávání takových údajů, čímž zaručí, že se zásah omezí na to, co je nezbytně nutné. “45 Soudní dvůr se dále specificky věnoval variantám uložených povinností, které jsou výjimkou uvedenou v čl. 15 odst. 1 umožněny. Jde o situace, které věcně spadají do rozsahu výjimky předmětného článku a zároveň jsou dodrženy záruky bránící zneužití dat a je limitován rozsah zpracovávaných údajů pouze na nezbytné a po nezbytně dlouhou dobu. ${ }^{46}$ Zároveň vždy platí podmínka, že legislativní opatření jsou povolena, pokud tato opatření „pomocí jasných a přesných pravidel zajištujỉ při uchovávání dotčených údajů dodržení souvisejících hmotněprávních a procesních podmínek a pokud subjekty údajů mají $k$ dispozici účinné záruky proti riziku zneužití. “47

V druhé otázce věnované čl. 15 odst. 1 směrnice 2002/58/ES pak Soudní dvůr konstatoval, že toto ustanovení nebrání národní právní úpravě, která zakládá povinnost poskytovatelů služeb elektronických komunikací provádět $\mathrm{v}$ reálném čase automatizovanou analýzu provozních a lokalizačních údajů, pokud existují takové záruky, které zajistí proporcionalitu a minimalizaci zásahu do chráněných práv.

Soudní dvưr v anotovaném rozhodnutí potvrdil argumentační linii, kterou bylo možné pozorovat již z minulých rozhodnutí zabývajících se čl. 15 odst. 1 směrnice 2002/58/ES a jasně nastavil limity možné národní úpravy data retention. $\mathrm{V}$ kontextu českého práva pak toto rozhodnutí může mít zajímavé dopady, protože ukazuje, že současná úprava je v rozporu s poža-

\footnotetext{
45 Bod 132 anotovaného rozhodnutí.

46 Bod 168 anotovaného rozhodnutí.

47 Závěr prvního výroku anotovaného rozhodnutí.
} 
davky směrnice a unijního práva, a to i přes závěry nálezu ÚS ve věci Data Retention III. $^{48}$

Autor: JM

\section{SOUHLAS SE ZPRACOVÁNÍM OSOBNÍCH ÚDAJŮ A DŮKAZNí BŘEMENO}

Soud: $\quad$ Soudní dvůr Evropské unie

Věc: $\quad$ C-61/19 (Orange Romania SA)

Datum: $\quad$ 11. 11. 2020

Dostupnost: curia.europa.eu

Společnost Orange România SA uzavírala během března 2018 se svými zákazníky smlouvy o poskytování telekomunikačních služeb, v nichž bylo předzaškrtnuté políčko, jímž měli zákazníci souhlasit s uchováváním kopií jejich dokladů totožnosti. Odmítnutí přitom bylo dle interních prodejních instrukcí možné pouze pokud byl zákazníkem před podpisem smlouvy vyplněn speciální formulářr.

Rumunský úřad pro ochranu osobních údajů uložil za tuto praxi svým rozhodnutím ze dne 28. 3. 2018 společnosti Orange România SA pokutu, ${ }^{49}$ proti čemuž podala společnost Orange România SA žalobu k soudu prvního stupně v Bukurešti. Soud se následně obrátil na Soudní dvůr Evropské unie se dvěma předběžnými otázkami.

Předmětem předběžných otázek bylo, jaké podmínky musí být dle čl. 2 písm. h) Směrnice č. 95/46/ES ${ }^{50}$ splněny, aby mohl být projev vůle zákazníka považován za výslovný a vědomý, případně také svobodný? ${ }^{51}$

Směrnice 95/46 v čl. 2 písm. h) stanoví, že souhlasem subjektu údajů se rozumí „jakýkoli svobodný, výslovný a vědomý projev vůle, kterým subjekt

\footnotetext{
Nález Ústavního soudu ze dne 14. 5. 2019, sp. zn. Pl. ÚS 45/17.

49 Bod 21 anotovaného rozhodnutí.

50 Směrnice Evropského parlamentu a Rady 95/46/ES ze dne 24. ř́inna 1995 o ochraně fyzických osob v souvislosti se zpracováním osobních údajů a o volném pohybu těchto údajů.

51 Bod 27 anotovaného rozhodnutí.
} 
údajů dává své svolení $k$ tomu, aby osobní údaje, které se jej týkají, byly prèemětem zpracování."

Soudní dvůr Evropské unie konstatoval, že projev vůle dle čl. 2 písm. h) Směrnice 95/46 musí být výslovný v tom smyslu, že se musí konkrétně týkat zpracování dotčených údajů a nelze jej vyvodit z projevu vůle mající jiný účel. ${ }^{52}$ Pokud je tedy souhlas zachycen na písemném prohlášení týkajícím se také jiných skutečností, je nezbytné, aby byl souhlas se zpracováním osobních údajů udělen takovým způsobem, který je jasně odlišitelný od souhlasu s jinými skutečnostmi. ${ }^{53}$ Subjekt údajů by měl být také srozumitelně informován o typu údajů, totožnosti správce, době trvání, metodě a účelu zpracování, ${ }^{54}$ přičemž důkazní břemeno o výše uvedených skutečnostech tîží správce osobních údajů. ${ }^{55}$ Povinnost doložit souhlas zákazníků tudíž nelze splnit prostřednictvím požadavku na aktivní odmítnutí zpracování. $^{56}$

Okolnost, že uvedení zákazníci podepsali smlouvy obsahující zaškrtnuté políčko, sama o sobě neumožňuje prokázat takový souhlas, neexistují-li informace potvrzující, že toto ujednání bylo skutečně přečteno a pochopeno. $^{57}$

Autor: JK

\section{NESPLNĚNÍ POVINNOSTI IMPLEMENTOVAT POLICEJNÍ SMĚRNICI}

Soud: $\quad$ Soudní dvůr Evropské unie

Věc: $\quad$ C-658/19 (Evropská komise proti Španělsku)

Datum: 25. 2. 2021

Dostupnost: curia.europa.eu

\footnotetext{
52 Bod 38 anotovaného rozhodnutí a také rozsudek Soudního dvora ze dne 1. října 2019, Planet49, C-673/17, EU:C:2019:801, bod 58.

53 Bod 39 anotovaného rozhodnutí.

54 Bod 40 anotovaného rozhodnutí.

55 Bod 42 anotovaného rozhodnutí.

56 Bod 51 anotovaného rozhodnutí.

57 Bod 46 anotovaného rozhodnutí.
} 
Směrnice 2016/680 ze dne 27. dubna 2016 o ochraně fyzických osob v souvislosti se zpracováním osobních údajů příslušnými orgány za účelem prevence, vyšetřování, odhalování či stíhání trestných činů nebo výkonu trestů, o volném pohybu těchto údajů (dále jen „policejní směrnice“) měla být implementována členskými státy do 6. května 2018. Evropská komise ani po uplynutí lhůty stanovené předmětnou směrnicí neobdržela od Španělska informaci o přijetí opatření nezbytných pro dosažení souladu s požadavky policejní směrnice, podala tedy žalobu o určení nesplnění povinnosti. Španělsko nezpochybnilo nesplnění povinnosti, ${ }^{58}$ mělo ovšem za to, že měl být při určení výše penále zohledněn fakt, že komunikace s Evropskou komisí probíhala časově blízko před rozpuštěním národního parlamentu a zahájením volebního procesu. ${ }^{59} \mathrm{~V}$ této souvislosti Španělsko odkazovalo na povinnosti ctít národní identitu členských států dle čl. 4 odst. 2 SEU. ${ }^{60}$

Evropská komise za žalobou domáhala určení nesplnění povinnosti a uložení penále dle čl. 260 odst. 3 SFEU.

Dle čl. 63 policejní směrnice byly členské státy povinny do 6 . května 2018 přijmout a zveřejnit právní a správní předpisy nezbytné pro dosažení souladu s danou směrnicí a sdělit Evropské komisi znění takovéto národní právní úpravy.

Soudní dvůr v této souvislosti uvedl, že povinnost sdělit opatření provádějící směrnici spočívá $\mathrm{v}$ povinnosti uvést jedno či více vnitrostátních ustanovení, které zajištují provedení policejní směrnice. ${ }^{61}$ Poté je povinností Evropské komise prokázat, že některá prováděcí opatření zjevně nebyla přijata vůbec nebo se nevztahují na celé území členského státu, zkoumání správnosti provedení policejní směrnice již Soudnímu dvorů nepř́íluší. ${ }^{62}$ Soudní dvưr měl na základě komunikace mezi Španělskem a Evropskou komisí za prokázané, že Španělsko opatření provádějící policejní směrnici nesdělilo. ${ }^{63} \mathrm{~V}$ otázce výše penále Soudní dvưr uvedl, že se jedná o vhodný

\footnotetext{
58 Srov. bod 13 anotovaného rozhodnutí.

59 Srov. bod 25 anotovaného rozhodnutí.

60 Srov. bod 26 anotovaného rozhodnutí.

61 Srov. bod 30 anotovaného rozhodnutí.

62 Tamtéž.

63 Srov. bod 31 anotovaného rozhodnutí.
} 
prostředek k zajištění toho, aby Španělsko co nejrychleji ustalo v neplnění povinnosti vyplývající ze směrnice $2016 / 680 .{ }^{64}$ Vnitrostátní situace nemůže odůvodnit nedodržení povinností a lhůt vyplývajících z unijních směrnice, ani jejich opožděné nebo neúplné provedení. ${ }^{65}$ Uložením paušální částky má být dosaženo účinnému předcházení obdobnému porušování práva v budoucnu. ${ }^{66}$

Soudní dvůr tedy dospěl $\mathrm{k}$ závěru, že Španělsko nepřijetím právních a správních předpisů nezbytných pro dosažení souladu s policejní směrnicí a nesdělení předmětných opatření Evropské komisi, porušilo povinnosti vyplývající z čl. 63 policejní směrnice. Soudní dvưr uložil povinnosti uhradit paušální částku ve výši 15 mil. euro, a pro případ přetrvávajícího neplnění povinnosti ke dni vyhlášení rozsudku též denní penále ve výši 89 tis. Euro.

Autor: IK

\section{VYUŽITÍ ÚDAJŮ O ELEKTRONICKÉ KOMUNIKACI PRO VYŠETŘOVÁNÍ BĚŽNÉ KRIMINALITY}

Soud: $\quad$ Soudní dvůr Evropské unie

Věc: $\quad$ C-746/18 (Prokuratuur)

Datum: $\quad$ 2. 3. 2021

Dostupnost: curia.europa.eu

Paní H. K. byla odsouzena estonským soudem prvního stupně ke dvěma letům odnětí svobody za krádeže věcí a peněz, zneužití platebního prostředku a násilné jednání vůči dalším osobám, přičemž celková způsobené škoda se pohybovala $\mathrm{v}$ řádu tisíců euro. ${ }^{67}$

K odsouzení došlo mimo jiné na základě několika protokolů vycházejících z údajů o elektronické komunikaci, které vyšetřovací orgán získal od poskytovatele služeb elektronických telekomunikací během přípravného

\footnotetext{
64 Srov. bod 61 anotovaného rozhodnutí.

65 Srov. bod. 77 anotovaného rozhodnutí.

${ }^{66}$ Srov. bod 84 anotovaného rozhodnutí.

67 Bod 16 anotovaného rozhodnutí.
} 
řízení poté, co mu příslušné státní zastupitelství udělilo za tímto účelem několik povolení. ${ }^{68}$

Předmětem předběžných otázek bylo posouzení, zda dle unijního práva, zejména dle ustanovení čl. 15 odst. 1 směrnice 2002/58/ES, ve spojení s články 7,8 a 11 a s čl. 52 odst. 1 Listiny základních práv EU, představuje přístup $\mathrm{k}$ provozním a lokalizačním údajům natolik závažný zásah do dotčených základních práv, že tento přístup musí být omezen na boj proti závažné trestné činnosti. ${ }^{69}$ Soudní dvưr navíc také posuzoval, zda je v př́ípadě, kdy přístup $\mathrm{k}$ údajům schválilo státní zastupitelství, splněna podmínka předchozího přezkumu př́istupu $\mathrm{k}$ údajům ze strany soudu nebo nezávislého správního orgánu. ${ }^{70}$

Článek 15 odst. 1 shora uvedené směrnice umožňuje členským státům zasáhnout do soukromí elektronické komunikace jednotlivců v př́ípadě, kdy je to v demokratické společnosti nezbytné, vhodné a přiměřené pro (mimo jiné) prevenci, vyšetřování, odhalování a stíhání trestných činů. Takový zásah musí být nicméně v souladu se zásadami práva $\mathrm{EU}$, a tedy zejména se standardy garantovanými LZPEU jak jsou vykládány soudním dvorem.

Soudní dvůr z velké části odkazuje na minulé rozhodnutí Velkého senátu v obdobné věci, kde uznal možnost plošného sběru a uchování údajů o elektronické komunikaci stejně jako možnost př́stupu k těmto údajům ze strany orgánů veřejné moci. ${ }^{71}$ Soudní dvůr nicméně zdůraznil princip proporcionality takového zásahu, a tedy že rozsah př́stupu k údajům o elektronické komunikaci musí být přiměřený závažnosti stíhané trestné činnosti. $\mathrm{V}$ tomto ohledu bylo tedy konstatováno, že př́stup orgánů veřejné moci k souboru provozních nebo lokalizačních údajů, z nichž mohou vyplynout informace o komunikaci uživatele prostředku elektronické komunikace nebo o umístění koncových zařízení, která používá, a z nichž lze vyvodit přesné závěry o soukromém životě subjektů údajů, mohou odůvodnit pouze

\footnotetext{
68 Bod 17 anotovaného rozhodnutí.

69 První a druhá předběžná otázka anotovaného rozhodnutí - body 27-45.

70 Třetí předběžná otázka anotovaného rozhodnutí - body 46-59.

71 Rozsudek Soudního dvora ze dne 6. října 2020, La Quadrature du Net a další, C-511/18, C-512/18 a C-520/18, EU:C:2020:791.
} 
cíle spočívající v boji proti závažné trestné činnosti nebo předcházení závažnému ohrožení veřejné bezpečnosti. ${ }^{72}$

Pokud jde o otázku přístupu k předmětným údajům na základě rozhodnutí státního zastupitelství, Soudní dvůr konstatoval, že právo členského státu musí stanovit dostatečné procesní a hmotněprávní záruky proti zneužití této pravomoci. ${ }^{73}$ Unijní právo tak zejména brání takové národní právní úpravě, jako je ta estonská, která umožňuje zpřístupnění dat i jiných osob než podezřelých ze spáchání závažného trestného činu, a to navíc na základě žádosti každého státního zástupce bez předepsané formy a předchozího přezkumu soudem nebo jiným nezávislým orgánem. ${ }^{74}$

Velký senát Soudního dvora tímto svým rozhodnutím navázal na svou předchozí judikaturu v oblasti data retention a stanovil další limity pro přístup orgánů členských států k údajům o elektronických komunikací svých obyvatel. Anotovaný rozsudek však rozhodně nemůže být vnímán jako zákaz využívání těchto dat pro účely trestních řízení obzvláště pak v případě závažné trestné činnosti.

Autor: VB

\section{OSTATNí}

\section{IDENTIFIKACE A DATOVÉ SCHRÁNKY}

Soud: $\quad$ Nejvyšší soud

Věc: $\quad 27$ Cdo $143 / 2020$

Datum: 27. 10. 2020

Dostupnost: nsoud.cz

Společenství vlastníků jednotek reprezentované předsedou výboru se domáhalo změny či výmazu některých údajů v rejstř́ku společenství vlastníků. První návrh změn byl doručen rejstříku osobně předsedou výboru. Rejstříkový soud na základě tohoto návrhu společenství vlastníků vyzval k doplnění některých podkladů či opravě některých údajů. Společenství nemělo

\footnotetext{
72 Bod 35 anotovaného rozhodnutí.

73 Body 48 a 49 anotovaného rozhodnutí.

74 Body 49-54 anotovaného rozhodnutí.
} 
zřízenou datovou schránku (pro společenství vlastníků není datová schránka zřizována ze zákona, ale případně na žádost). Společenství na základě požadavků soudu doručilo některé podklady "osobně", některé byly doručeny prostřednictvím datové schránky předsedy výboru, kterou ale zřídil jako fyzická osoba.

Právě tento způsob elektronického doručení nebyl rejstř̌íkovým soudem akceptován, jelikož dle něj návrh nebyl podán předepsaným způsobem, tedy nebyl podepsán bud' elektronickým podpisem, nebo nebyl zaslán prostřednictvím datové schránky osoby, která takový návrh činí (tedy z datové schránky společenství vlastníků jednotek), ${ }^{75}$ kde by nastoupila fikce podpisu zmiňovaná mj. stanoviskem Nejvyššího soudu Plsn 1/2017, ze dne 5. 1. 2017. Hlavním argumentem nižších soudů, které se postupně případem zabývaly (a především Vrchního soudu v Olomouci) bylo s odkazem na předchozí rozhodovací praxi, že „úkon učiněný jinou osobou prostrèednictvím ,cizí datové schránky (např. podání fyzické osoby z datové schránky jejîho zaměstnavatele) nemá právní účinky, které zákon jinak dokumentu doručenému prostřednictvím datové schránky přiznává. “76

Proti tomuto rozhodnutí podalo společenství vlastníků dovolání k Nejvyššímu soudu, který jej shledal za př́ípustné.

Nejvyšší soud se tak zabýval zejména formalistickým přístupem nižších soudů a zvažoval, jestli př́slušná datová schránka (zřízena pro fyzickou osobu) dostatečně identifikuje tuto osobu, která ale jedná $\mathrm{v}$ roli předsedy výboru. Postupně shrnul relevantní právní úpravu a zdůraznil, že fyzická osoba, oprávněná jednat jménem právnické osoby (tedy $\mathrm{v}$ daném případě předseda výboru) „může jménem právnické osoby učinit elektronické podání [...] i ze své datové schránky (z datové schránky fyzické osoby podle $\S 8$ odst. 1 zákona o elektronických úkonech)." ${ }^{77}$ Je-li pak z podání zřejmé, že tato osoba jedná jménem právnické osoby, jde o podání právnické osoby. $\mathrm{V}$ tomto kontextu pak soud shrnul, že podání učiněné $\mathrm{z}$ datové schránky fyzické osoby, ze kterého je ale jasné, že tato osoba jedná za osobu

\footnotetext{
75 Bod 7 anotovaného rozhodnutí.

76 Bod 20 anotovaného rozhodnutí.

77 Bod 37 anotovaného rozhodnutí.
} 
právnickou (tedy že se jedná o předsedu jednajícího za společenství vlastníků) je nutno posuzovat za podání dostatečné a předchozí právní posouzení nižšími soudy za nesprávné.

Toto rozhodnutí je nutno považovat za další pozitivní krok směrem k opuštění od přepjatého formalismu, jelikož fakticky došlo k dostatečné identifikaci př́slušné osoby a jen na tom základě, že bylo $\mathrm{k}$ podání využito „cizí“ datové schránky, nelze takové podání formálně odmítnout.

Autor: PL

\section{NEOPRÁVNĚNÝ PŘÍSTUP K FACEBOOK ÚČTU}

Soud: $\quad$ Nejvyšší soud

Věc: $\quad 7$ Tdo $1134 / 2020$

Datum: $\quad$ 4. 11.2020

Dostupnost: nsoud.cz

Obviněný se mezi lety 2009 a 2018 dopustil opakovaného a dlouhodobého týrání své družky. Krom hrubých slovních nadávek a fyzického násilí využil znalosti hesla k jejímu účtu na sociální síti Facebook, aby ji znemožnil přístup $\mathrm{k}$ tomuto účtu. ${ }^{78}$

Okresní soud v Českých Budějovicích dne 17. 12. 2019 shledal obviněného vinným z trestných činů týrání osoby žijící ve společném obydlí podle § 199 odst. 1, 2 písm. b), d) trestního zákoníku, ${ }^{79}$ a neoprávněného přístupu $\mathrm{k}$ počítačovému systému a nosiči informací podle $\S 230$ odst. 1 TZ. Krajský soud v Českých Budějovicích následně odvolání obou stran zamítl jako nedůvodná. ${ }^{80}$ Proti zamítavému usnesení podal obviněný dovolání k Nejvyššímu soudu.

Předmětem sporu bylo mimo jiné, zda obviněný svévolným přístupem do Účtu své družky prostřednictvím hesla, které znal již z původní registrace účtu, překonal bezpečnostní opatření k účtu dle $\S 230$ TZ.

\footnotetext{
78 Bod 2 anotovaného rozhodnutí.

79 Zákon č. 40/2009 Sb., Zákon trestní zákoník, ve znění pozdějších předpisů.

80 Bod 4 anotovaného rozhodnutí.
} 
Předmětný trestný čin neoprávněného přístupu k počítačovému systému a nosiči informací dle $\S 230$ TZ spáchá ten kdo „překoná bezpečnostní opatrení, a tím neoprávněně získá přístup $k$ počítačovému systému nebo $k$ jeho části $[\ldots]^{\prime}$.

Nejvyšší soud konstatoval, že sociální sít Facebook nelze apriori považovat za soukromou ani veřejnou, ale vždy záleží na konkrétním nastavení míry soukromí účtu nebo konkrétního příspěvku jeho uživatelem. ${ }^{81}$ Ačkoliv tedy obviněný kdysi družce založil Google-účet, skrze který se ke svému účtu na Facebook.com přihlašovala, nebylo dohodnuto, že by mohl obviněný $\mathrm{k}$ družčině účtu přistupovat. ${ }^{82}$ Nejvyšší soud tedy seznal, že účet byl založený pouze pro družku a obviněný do něj vstoupil bez jejího vědomí. Jako překonání bezpečnostního opatření pak soud identifikoval již samotné využití znalosti hesla obviněným, přičemž za přiléhavé označil přirovnání účtu k obydlí, a bezpečnostního opatření ke klíči, který obviněný využil $\mathrm{k}$ neoprávněnému přístupu. ${ }^{83}$

Nejvyšší soud v předmětném rozhodnutí postavil na jisto, že jakýkoliv neoprávněný přístup do osobního účtu bez ohledu na způsob, jakým bylo heslo či jiné bezpečnostní opatření překonáno, je překonáním bezpečnostního opatření dle $\S 230$ TZ. Dovolací nárok obviněného byl proto odmítnut jako zjevně neopodstatněný.

Autor: JK

\section{SPOTŘEBITELSKÁ PRÁVA A NFC FUNKCE PLATEBNÍCH KARET}

Soud: $\quad$ Soudní dvůr Evropské unie

Věc: $\quad$ C-287/19 (DenizBank)

Datum: 11. 11. 2020

Dostupnost: curia.europa.eu

\footnotetext{
81 Bod 38 anotovaného rozhodnutí.

82 Bod 39 anotovaného rozhodnutí.

83 Bod 40 anotovaného rozhodnutí.
} 
Rakouská bankovní instituce DenizBank poskytuje možnost využívání bankovních karet vybavených $\mathrm{NFC}^{84}$ pro bezkontaktní platby do $25 €$ bez nutnosti zadat PIN. V rámci obchodních podmínek souvisejících s užíváním takového způsobu platby bylo mj. uvedeno, že „změny všeobecných obchodních podmínek týkajících se debetních karet jsou nabídnuty klientovi nejpozději dva měsíce před datem stanoveným pro jejich vstup $v$ platnost a že se má za to, že klient tyto změny přijal, pokud je před tímto datem výslovně neodmítne“, dále pak že bankovní instituce „není povinna poskytnout doklad o tom, že platby malých částek provedené bez zadání osobního kódu [...] byly autorizovány“ a zároveň se zproštuje „odpovědnosti a veškerých povinností $k$ náhradě $v$ př́padě, že takovéto platební transakce nebyly autorizovány držitelem karty, “85

Proti takto formulovaným obchodním podmínkám podalo žalobu u rakouského soudu sdružení, které je dle právní úpravy legitimováno k ochraně zájmů spotřebitelů. Rakouské soudy postupně shledaly daná ustanovení za problematická, rakouský Nejvyšší soud pro ověření některých nejasností souvisejících s užíváním takových platebních prostředků formuloval následující předběžné otázky v souvislosti s úpravou dle směrnice PSD2. ${ }^{86}$

Rakouský soud se dotázal, (i) jestli poskytovatel platebních služeb může jednostranně měnit podmínky rámcové smlouvy na základě souhlasu uděleného mlčky, (ii) jestli lze NFC posoudit jako platební nástroj, (iii) jestli se $\mathrm{v}$ případě použití NFC jedná o anonymní použití platebního prostředku a konečně (iv) jestli v případě NFC plateb bez zadání PIN nese poskytovatel ztrátu za provedené platby.

V rámci první (i) výše uvedené předběžné otázky Soudní dvůr zdůraznil, že je patrné, že fikce mlčky uděleného souhlasu se týká jen změn ob-

${ }^{84}$ Jedná se o technologii, která slouží k bezdrátové komunikaci mezi zařízeními, v konkrétním případě $\mathrm{k}$ bezkontaktním platbám.

${ }^{85}$ Nejedná se však o jediné relevantní ustanovení obchodních podmínek, více viz bod 33 anotovaného rozhodnutí.

${ }^{86}$ Směrnice Evropského parlamentu a Rady (EU) 2015/2366 ze dne 25. listopadu 2015 o platebních službách na vnitřním trhu, kterou se mění směrnice 2002/65/ES, 2009/110/ES a 2013/36/EU a nařízení (EU) č. 1093/2010 a zrušuje směrnice 2007/64/ES. 
chodních podmínek, nikoli uzavření nové smlouvy. ${ }^{87}$ Nadto rovněž zdůraznil, že dané ujednání „musí splňovat požadavky dobré víry, vyváženosti a transparentnosti stanovené směrnicí $93 / 13 .{ }^{\text {“88 }} \mathrm{V}$ této otázce tak soud rozhodl, že směrnice PSD2 neomezuje takový charakter smluvních ujednání, která lze měnit mlčky, ale pokud je uživatelem platebních služeb spotřebitel, je nutno použít směrnici o nepřiměřených podmínkách ve spotřebitelských smlouvách. ${ }^{89}$ V souvislosti s druhou (ii) otázkou pak soud uvedl, že NFC je vzhledem ke své specifičnosti právně oddělitelná od ostatních funkcí karty a může být posuzována jako samostatný platební prostředek. ${ }^{90}$ To má za důsledek, že se široká míra ochrany na základě směrnice PSD2 vztahuje i na tento způsob plateb (a poskytuje tedy mj. vysoký standard ochrany spotřebitele). ${ }^{91} \mathrm{~V}$ rámci třetí (iii) otázky anonymního použití platebního prostředku Soudní dvůr zdůraznil, že v daném případě se jedná o anonymní platbu, jelikož (např. v případě krádeže) je platební nástroj používán anonymně a poskytovatel tak není schopen prokázat, že platební transakce byla opravdu autorizována oprávněným držitelem karty (v situaci, kdy není zadáván PIN). A konečně v př́padě čtvrté (iv) položené otázky, která souvisí s odpovědností poskytovatele služeb za neoprávněnou platbu (a nesení související ztráty) soud zdůraznil, že se poskytovatel platebních služeb nemůže omezit jen „na tvrzení, že dotyčný platební prostředek není možné zablokovat nebo zabránit jeho dalšímu použití, ačkoli s ohledem na objektivní stav dostupných technických poznatkủ nelze takovou nemožnost prokázat. “92

Dané rozhodnutí tak alespoň částečně vyjasnilo, za jakých podmínek je možno měnit obchodní podmínky a dále $\mathrm{v}$ rámci související právní úpravy přistupovat $\mathrm{k}$ charakteru NFC plateb (zejména bez potřeby zadat PIN, kdy se jedná o anonymní platbu realizovanou specifickým platebním prostř̌edkem). Soudní dvůr nicméně zdůraznil, že samotná bankovní institu-

\footnotetext{
87 Bod 47 anotovaného rozhodnutí.

88 Bod 65 anotovaného rozhodnutí.

89 Směrnice Rady 93/13/EHS ze dne 5. dubna 1993 o nepřiměřených podmínkách ve spotřebitelských smlouvách.

90 Bod 77 anotovaného rozhodnutí.

91 Bod 78 anotovaného rozhodnutí.

92 Bod 106 anotovaného rozhodnutí.
} 
ce nese riziko ztráty za neoprávněnou platbu (pokud je například karta odcizena), pokud dostatečně neprokáže, že je $\mathrm{v}$ případě nahlášení schopna platební kartu adekvátně zablokovat ( $v$ okamžiku, kdy je tedy nahlášena ztráta karty, jsou další proběhlé platby de facto hrazeny samotnou bankovní institucí).

Autor: PL

\section{PRÁVO NA INFORMACE O PLATECH A ODMĚNÁCH - HLÍDACÍ PES DEMOKRACIE}

Soud: $\quad$ Nejvyšší správní soud

Věc: $\quad 5$ As $440 / 2019$

Datum: $\quad$ 5. 3. 2021

Dostupnost: nssoud.cz

Žalobce se žádostí doručenou Krajskému úřadu Ústeckého kraje dne 27. 10. 2014 domáhal s odkazem na zákon č. 106/1999 Sb., sdělení informací o platu a odměnách vedoucích jednotlivých odborů, poradců hejtmana, náměstků a radních Ústeckého kraje a ředitele uvedeného krajského úřadu, přičemž požadoval mimo jiné zdůvodnění případných mimořádných odměn. ${ }^{93}$

Této žádosti žalovaný krajský úřad opakovaně odmítl vyhovět, přičemž jeho rozhodnutí byla opakovaně rušena nadřízeným správním orgánem (celkem $12 x$ ). ${ }^{94}$ Žalovaný i potřinácté odmítl informace vydat, přičemž vyjádřil nesouhlas s výkladem § 8b InfZ Nejvyššího správního soudu ${ }^{95} \cdot{ }^{96}$ Toto rozhodnutí žalobce napadl u krajského soudu, což bylo soudem shledáno jako přípustný postup z důvodu procesní minulosti, žaloba však nebyla

\footnotetext{
93 Viz bod 1 anotovaného rozhodnutí.

94 Viz bod 2 anotovaného rozhodnutí.

95 Viz rozsudek ze dne 27. 5. 2011, č.j. 5 As 57/2010-79. Zároveň žalovaný vyjádřil své přesvědčení, že žalobce zneužívá své právo na informace, nebot' už jednou poskytnutou informaci zveřejnil ve svém článku.

96 Viz body 3-5 anotovaného rozhodnutí.
} 
shledána důvodnou, nebot nebyly podle krajského soudu naplněny podmínky stanovené judikaturou Ústavního soudu ${ }^{97} .^{98}$

Proti rozsudku krajského soudu podal žalobce kasační stížnost, která se týkala výkladu § 8b zákona č. 106/1999 Sb., a aplikace rozsudku ESLP ve věci Magyar Helsinki Bizottság a nálezu ÚS ze dne 17.10. 2017, sp. Zn. IV. ÚS 1378/16.

Ustanovení § 8b zákona č. 106/1999 Sb. zavazuje povinné subjekty poskytnout informace o příjemcích veřejných prostředků, přičemž podmínky $\mathrm{v}$ př́padě informací o platu a odměnách zaměstnance specifikoval ÚS ve zmíněném nálezu. ${ }^{99}$

NSS upozornil, že jak ESLP, tak ÚS potvrdily, že právo na informace není právem absolutním, je tedy nutné vždy posoudit zvláště to, zda je uplatňováno ve veřejném zájmu či jako součást svobody projevu ${ }^{100}$ a jak moc zasahuje do dalších práv. ${ }^{101}$ NSS ovšem konstatoval, že krajský soud provedl tento test proporcionality chybně a v rozporu se závěry Ús. ${ }^{102}$ Test pak provedl sám, přičemž upozornil na klíčová pochybení krajského soudu. Za prvé kontrola, zda se státní orgány řídí judikaturou správních soudů, je bez pochyb věcí veřejného zájmu. ${ }^{103}$ Dále pak není možné v celém procesu vycházet toliko z informací v samotné žádosti, ale i z informací, které žadatel uvede $\mathrm{v}$ rámci navazujících řízení, žalovanému tak muselo být mi-

97 Viz nálezy Ústavního soudu ze dne 17. 10. 2017, sp. zn. IV. ÚS 1378/16, a ze dne 3. 4. 2018, sp. zn. IV. ÚS 1200/16. Žalobce deklaroval zájem zjistit ochotu státních orgánů respektovat judikaturu NSS, nikoliv přispění $k$ veřejné debatě či dozoru veřejnosti, což mu bylo krajským soudem vytknuto. Zmíněná kritéria však ÚS formuloval až tři roky po podání žalobcovy žádosti.

98 Viz body 6-8 anotovaného rozhodnutí.

99 Jedná se $o$ a) účelem vyžádání informace je přispět $k$ diskusi o věcech veřejného zájmu; b) informace sama se týká veřejného zájmu; c) žadatel vystupuje v roli tzv. „společenského hlídacího psa“, a d) informace existuje a je dostupná.

${ }^{100}$ Mimo jiné poukázal na podobnost s rozsudkem ze dne 29. 9. 2020, č. j. 4 As 91/2020-45. Viz body 28-30 anotovaného rozhodnutí.

${ }^{101}$ Viz bod 29 anotovaného rozhodnutí.

${ }^{102}$ Viz body 31-33 anotovaného rozhodnutí. Mimo jiné podotýká, že „žalovaný si prìtom $v$ testu

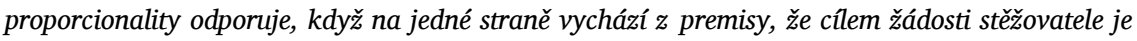
kontrola poskytování finančního plnění žalovaným, na druhé straně konstatuje, že tomu tak ve skutečnosti není."

${ }^{103}$ Viz bod 37 anotovaného rozhodnutí. 
nimálně při druhém řízení o poskytnutí informací již jasné, že žalobce je novinář a tudíž „hlídací pes demokracie“. ${ }^{104}$ A nakonec - kdyby se relevantní zaměstnanci vůbec nepodíleli na výkonu veřejné moci, veřejný zájem na vydání takové informace by zde nebyl, v tomto případě se však podílejí značně. ${ }^{105}$

NSS tak konstatoval důvodnost kasační stížnosti a zrušil napadený rozsudek krajského soudu i původní správní rozhodnutí, přičemž žalovaného zavázal vysloveným právním názorem. Nejvyšší správní soud nad rámec podané kasační stížnosti otevřeně konstatoval pohoršení a nelibost nad jednáním žalovaného, kdy opakovaně a záměrně postupoval v rozporu $\mathrm{s}(\mathrm{v}$ dané době) ustálenou a nezpochybněnou judikaturou NSS, přestože byla později korigována ze strany ÚS, i v rozporu s názory odvolacího správního orgánu. Dále vytkl zcela otevřeně obstrukční jednání a zvůli žalovaného jakožto i naprosto flagrantní případ podjatosti úřední osoby. ${ }^{106}$

Autor: JV

Toto dílo lze užít v souladu s licenčními podmínkami Creative Commons BY-SA 4.0 International (http://creativecommons.org/licenses/by-sa/4.0/legalcode).

\footnotetext{
${ }^{104}$ Viz body 30 a 35 anotovaného rozhodnutí.

${ }^{105}$ Viz bod 36 anotovaného rozhodnutí.

${ }^{106}$ Osoby, o jejichž platech se rozhodovalo, vydávaly rozhodnutí o odmítnutí poskytnutí informací. Viz body 22-23 anotovaného rozhodnutí.
} 